\title{
Researching Women's Film History
}

\author{
MELANIE BELL \\ University of Leeds, UK \\ SHELLEY COBB \\ University of Southampton, UK \\ CHRISTINE GLEDHILL \\ University of Leeds, UK \\ DEBASHREE MUKHERJEE \\ Columbia University, USA \\ LARAINE PORTER \\ De Montfort University, UK \\ RASHMI SAWHNEY \\ Christ University, India \\ ULRIKE SIEGLOHR \\ Staffordshire University, UK
}

While 1970s/1980s feminist film theory questioned the representability of women within a male-dominated industry, renewed interest in early film history revealed unexpected numbers of women film makers. The international Women Film Pioneers Project (WFPP), an ever-growing database housed at Columbia University, New York, documents research into the pioneering work of women in cinema's first crucial decades as it became a mass and transnational medium. A surge of monographs has followed, focusing on women's diverse careers, the gendering of film studio organization and practices, and the cultural impacts of female audiences, campaigners, journalists, and critics. These discoveries are emerging in festival and film theater programming, film education, and local cultural activity. In Britain, the Women's Film \& Television History Network-UK/Ireland, encourages research across the barriers between silence and sound, cinema and television. In what follows, the Network records key issues and figures emerging from the project of women's film history.

Feminist theory's encounter with film history questions the gendered assumptions that determine historical methods and what counts historically. Following Gertrude Stein, Jane Gaines (2018) asks: How does the historian know? The term "history" is ambiguous, referring both to what happened and its narrativization as "story." Where we look for evidence and how it is interpreted depends on the questions asked, underlying gendered expectations, and the conventions of narrative construction. Historical knowledge is provisional: new questions emerge; new discoveries are made that contradict or alter the known. So, asked Shelley Stamp at the 2018 Doing Women's Film and 
Television History conference, why, despite publication of so much rigorous research, are women filmmakers still ignored in recent cinema histories?

However, we must ask what we are trying to do by recalling such women from oblivion. On one hand, we seek to avoid the "great men" approach of traditional history, but on the other, to recover individual women for feminist history. The temptation is to look for precursors, women like us, but as Kim Tomadjoglou (2015) points out, the reclaimed "mother of cinema" Alice Guy Blaché's gender-challenging comedies also field regressive class and/or racial stereotypes, requiring us to negotiate "her times" with ours. Equally, their films may differ from today's technical and aesthetic standards. To admit them into film history, then, means recasting critical canons, conventional know-how, and dominant conceptions of cinema. Standard film histories allot scant space to avant-garde experiment, documentary, and animation, sectors often explored sympathetically by women. And the field of amateur women's filmmaking is only just being addressed. As Gaines (2018) argues, although we can never know the lived experience of the women we research, we may imagine who they are for us, seeking signs in their past of an anticipated future that we now live. Perhaps, as Dall'Asta and Gaines (2015) argue, the recently discovered but not until recently screened Umanitá, Elvira Giallanella's surreal pacifist film made in 1918, had to wait for women's film history in order to find its audience, one that celebrates its past "failure" as, now, an extraordinary success.

\section{Women Film Pioneers}

Women were present in the emergence of cinema from the start, though not necessarily in the places traditional historians have looked. A lack of both publicized credits and clearly defined roles in cinema's early years impede research. However, the history of cinema's invention-conventionally divided between the French Lumière brothers for documentary record and George Méliès for fictive fantasy-is now disturbed by reinsertion of the work of Louis Gaumont's secretary, Alice Guy, claiming her equal precedence with them in realizing cinema's future fictional possibilities. From her secretarial role, she moved to head of film production at Gaumont, where, as scenarist, director and/or producer, she turned out hundreds of short films, often ribald, gender-bending comedies, which for a long time were "lost," ignored, or credited to others.

In many countries, filmmaking emerged from family-run, artisanal workshops and businesses. In 1899 Britain, Cecil Hepworth left his photographic business to set up a film studio near London, drawing on the help of his wife, Margaret, as actress, scenario writer, and general adviser, while later relying on his scriptwriter, Blanche MacIntosh and lead actress, Alma Taylor. Common to such enterprises, when filmmaking know-how was still developing, was a fluidity and gender flexibility between roles. But, while film history accords credit to the director, later reinforced by festival retrospectives and monographs, the creative input of many roles, especially those undertaken by women-scripting, costume design, hair-dressing, continuity, production secretary-has gone uncredited, undervalued, and unrecorded. Equally neglected is the work of distribution, exhibition, and company or cinema management 
as well as the work of developing, printing, and hand coloring in the film laboratories, much of it performed by women (see later).

Evidence of such contributions in the pioneer period is scant, while most films are lost through neglect, deliberate destruction, lack of preservation, wars, or archival fires. Considerable detective work is required among often unorthodox sources. For missing films there may be reviews, company catalogs, press books, production stills, censorship records. But evidence of women's careers-as they switched roles, changed names, or followed opportunities to different countries-often depends on passing references in trade journals, company reports, biographies, memoirs, gossip columns, marriage certificates, census returns, shipping records, and so on. Scriptwriter, Mary Murillo, for example, born Mary O'Connor in the United Kingdom but of Irish parentage, initially proved elusive. Tracked by Luke McKernan (2015), via shipping records, to America as a chorus girl, she eventually emerges as the highly paid chief scriptwriter for Fox in 1915-1917 and later Norma Talmadge Productions up to 1922, after which she disappears from record.

The common pattern of collaboration or partnership makes retrieving and assessing women's contributions problematic, since the public face of a company or directorial credit for a film was often taken by, and is frequently assumed to belong to, men, as evidenced in the "forgetting" of Alice Guy's role in cinema's development. Following her marriage in 1907 to American Herbert Blaché, the couple moved to New Jersey to work for Pathé, where in 1910 she founded Solax, wielding creative and managerial control up to its demise in 1914, for a long time obscured under her husband's name. Whereas Guy attempted through her later memoirs and interviews to reclaim her place in film history as the "mother" of cinema, Alma Reville, suppressing her earlier silent cinema experience as editor, assistant director, and script-developer, continued providing unseen help to her husband, auteur-in-chief Alfred Hitchcock, throughout his career. As Alice Guy had done earlier, Britain's highly respected scenarist, Lydia Hayward, emphasized co-creation, arguing that films were the product of many minds over which no one could claim sole authorship (Hayward, 1927). As yet, however, with critical emphasis on singular authorship, we have no vocabulary to recognize, let alone evaluate, collaboration.

By far the largest number of women filmmakers are found working in the crucial decades of Hollywood's emergence to worldwide dominance, from the 1910s into the early 1920s. According to Karen Mahar (2006), American women's ascendency began with the nickelodeon boom from 1907 through the 1910s, which, demanding longer, character-based story films, gave actresses prominence, thereby creating the first screen stars-Florence Lawrence, Florence Turner, Marion Leonard, and Mary Pickford. For the new industry, under threat of federal censorship for its supposed bad influence, the stars' large followings of middle-class women promised respectability, enabling them to negotiate higher remuneration, creative control, and their own companies. At the same time, Mahar notes, the relative gender egalitarianism of the acting profession and the film studio's initial role flexibility enabled actresses to acquire production skills.

Notable for its employment of women to write, direct, and act in their scripts or head production units was Universal. Thus, ostensibly sharing roles with her husband, Phillips Smalley, Lois Weber became one of the most highly regarded, highly paid 
filmmakers of the time, running her own company, scripting, acting, or directing, while raising the profile of cinema with social-conscience films on controversial topics such as abortion, poverty, social and religious hypocrisy: Hypocrites (1914) scandalously employed a female nude to represent the "naked" truth. If Weber spoke to progressive middle-class women, equally important was the appeal to modern working-class girls of the death-defying adventures of the "serial queens"-Pearl White, Gene Gautier, Helen Holmes, Grace Cunard, Ruth Roland-or of slapstick, convention-breaking, comediennes-Mabel Normand, Fay Tincher, Marie Dressler, Louise Fazenda-who all ran their own companies, produced or scripted their films, albeit often in nominal partnership with husbands or male colleagues.

While, according to Gaines (2018), at least 60 American women worked as director or producer during the 1910s, these numbers shrank thereafter. By the late 1910s women's companies were failing. The reason why, however, was not simply deliberate exclusion. The conditions of film production had emerged from a convergence of industrial, social, and cultural processes favorable to female perspectives and participation, not least in recognition of changing gender identities essential to rising consumer capitalism and white-collar employment, drawing middle- and lower-class women into the public sphere. But the 1915 Supreme Court decree defining cinema as business not art-thus unable to claim protection of free speech for controversial issues-encouraged the studios toward entertainment rather than uplift. Increasingly they avoided risqué serial queen adventures and slapstick comedies, genres provoking new censorship threats, not least, Mahar (2006) notes, from women's organizations. Playful transgression of still prevalent traditional gender identities receded.

Filmmaking was now America's largest industry, demanding high investment; banks watched profit margins. Control of the production process shifted from director and colleagues on the set to the central producer, who oversaw the allocation and progress of all roles and was answerable to the studio's investors. As Cooper (2013) records, Universal, undergoing systematization, scheduled production into genres more clearly defined and easily salable by traditional gender description, leaving women filmmakers restricted to what would become known as "women's pictures." Professionalization, argues Mahar (2006), meant the masculinization of most filmmaking departments - not least through craft associations organized as fraternities-enabling men more easily to cross from failing independent companies into the five majors constituted by the late 1920s, while many women pioneers dropped out. Moreover, the building of picture palaces in the 1920s, meant the experience of film-going became a key attraction, reducing the stars' power. A new form of pleasure-oriented fantasy film emerged, associated with Cecil B. DeMille and his collaborating scriptwriter, Jeanie Macpherson. Lois Weber's high moral mission for the movies now appeared outdated, displaced by the jazz-age's focus on personal freedoms.

But this was not the end of women filmmakers. As Giuliana Muscio (2015) shows, the insights of women writers in shaping American cinema as modern entertainment was crucial, whether as sources of stories adapted, as scriptwriters, or as heads of story departments. Notable in this regard was Frances Marion, whose perceptive screenplays shaped the careers of Mary Pickford, Greta Garbo, and others, and who helped to revive Marie Dressler's fortunes in the early 1930s. Arguably, when cinema began to 
talk, women's discursive capabilities and dialogue skills-already dominating popular fiction, magazine writing, and important to silent film titling-became central to its expanding domain. Writing, as the least "sex-typed craft" (Mahar, 2006, p. 182), not only offered women an entrée into production-for example, Nell Shipman, Jeanie McPherson, June Mathis, Ruth Ann Baldwin, Ida May Park—but became the means to cross from silent to sound era. As Angela Martin (1998) records, many of the scripts of film noir-the cycle most discussed in terms of male angst-were written by women.

Beyond the studio floor, women writers were active in creating links between studios, stars, and audiences through fan magazine columns and in reflective criticism and commentary. "Cinema exists to please women ... but women make poor use of their power," claimed the enthusiastic Iris Barry, among the first film critics, founder member of London's Film Society, and in 1935 first head of MOMA's film department (Davy, 1926). For Alma Taylor, cinema established “the Modern Girl's right to a good time” ... providing "a form of entertainment ... peculiarly [women's] own” (Lant, 2006, p. 7). The relation between cinema and women was thus a sign of an intensifying, if ambiguous, modernity, driven by a consumer capitalism that opened up opportunities-if often exploitive-and closed them down again, until the rise of second-wave feminism.

Meanwhile, outside the main American studios, another history, recorded by the Women Film Pioneers Project, is emerging of African American women, who in the 1920s, while working in precarious independence and, often collaborating with husbands, sought to make films for Black audiences that countered racist stereotypes, encouraging moral and religious uplift-Eloyce King Patrick Gist_or telling stories, both fictional-Tressie Saunders, Maria P. Williams-and ethnographic-Zora Neil Hurston-of African American life. Alice B. Russell both acted in and managed the productions of her husband, the celebrated African American filmmaker, Oscar Micheaux, as did Eslanda Goode Robeson for Paul Robeson. Notably, according to Aimee Dixon (2016), Drusilla Dunjee Houston, a long-standing critic of Thomas Dixon's racist work, wrote a never-produced screenplay to counter D. W. Griffith's The Birth of a Nation (1915), his controversial adaptation of Dixon's The Clansman, a script that might now also be celebrated as a beautifully courageous "failure."

Beyond North America, diverse histories of women filmmakers are similarly emerging worldwide. In Naples, Elvira Notari founded Dora Film in 1912 with her husband as cameraman and young son as actor, gaining the nickname, "the General" for her autocratic methods. By 1930 she had scripted and directed 60 feature films, noted for the realist settings of their melodramatic scenarios. The Danish Asta Nielsen, attained worldwide popularity in German films of the 1910s, made in collaboration with her director husband, Urban Gad, in productions that she claimed to control. After their separation, she twice set up production companies of her own, making her celebrated film as a cross-dressing Hamlet in 1921. But, according to Allen (2017), the increasing power of the male director in German cinema led to stormy relationships in the later 1920s.

While all filmmaking during the pioneer period was experimental, European women were at the forefront of cinema's diversity. In war-torn France, opportunities for women opened up in the absence of men at the front. Thus in 1915, feminist campaigner and critic Germaine Dulac, with support from her husband from the 
warfront, founded a film company with writer/scenarist Irène Hillel-Erlanger, making innovative feature films dealing with contemporary problems of gender identity, while also initiating the ciné-club movement throughout France and developing her goal of "pure cinema" freed from the other arts. In the 1920s, pragmatically combining commercial with avant-garde production, she made the impressionist The Smiling Madame Beudet (1922/1923) and The Seashell and The Clergyman (1928)-the latter mired in controversy with its scriptwriter, Antonin Artaud-while developing innovative documentary and newsreel techniques. In late teens Germany, Lotte Reiniger developed film animation, using silhouettes and shadow puppetry, writing and directing her scripts, which from 1921 her husband photographed, her notable achievement being the first feature-length animation, The Adventures of Prince Achmed (1923-1926). In the USSR, Esther (Esfir) Shub, drawing on her experience of re-editing old films and emerging techniques of montage, developed a new form of compilation documentary to record the history and early years of Soviet Russia, notably The Fall of the Romanov Dynasty (1928).

While the first films were shown almost simultaneously around the world, conditions for the development of film production varied. Emerging industrialization and modernization, degrees of national autonomy or colonization, existing cultural traditions, and the gendering of social relations all created different contexts for the development of local film studios and the opportunities or not afforded to women. As recorded by Hershfield and Torres San Martín (2013), histories of women filmmakers in Latin American cinemas differ according to country, distinguishing the revolutionary context of Mexico-in which Mimí Derba and Adela Sequeyro sought to help build a national cinema to counter Hollywood stereotypes-from the cosmopolitanism of Argentina, incorporating waves of artists and writers from Europe, or from the Catholic-dominated conservatism of Chile, where prohibition against women attending cinemas unchaperoned meant only those from the social and intellectual elite could break into male-dominated film production.

For many countries, particularly those under colonialism, American and European films brought new images of women, disturbing traditional patriarchal gender relations and alarming the authorities. However, in China, operatic traditions of all-female casting allowed independent-minded women to move from stage to screen-acting, largely in the 1920s through a silent period prolonged into the 1930s. As elsewhere, their popularity as screen stars-for example, Fan Xuepeng, as a martial arts/magic spirit actress-enabled some to take, often uncredited, control of aspects of production, in Fan's case, of special effects (Yang, 2017). In other cases, disagreements with male company owners led some stars to set up their own productions, write their own scripts, or to direct their own films, for example, the financially exploited Helen Wang, or unruly fashionista Yang Naimei (Wei, 2017, 2018).

The transition to sound, dependent on technological development and further huge bank investment, only served to consolidate the masculinization of most above-the-line roles, on the assumption that authority on the set and over production schedules required male attributes. In America in the 1910s, when filmmaking was a game, women found the opportunity to become company owners and film directors. But the only American woman to cross the sound barrier into the 1930s and 1940s 
as film director, Dorothy Arzner, did so through skills learned earlier as an efficient editor, promising delivery on time and in budget, as well as a persona affecting seeming masculine reticence and control (Mahar, 2006). As Cooper (2013) records, after employing the highest number of women directors in the 1910s, it was not until 1982 that Universal again gave work to a female director.

\section{Women and the Transition to Sound Cinema in Britain}

The development of sound technology is written as the history of male scientific invention by men, for example, Eugene Lauste, Alexander Graham Bell, Thomas Edison, and Lee de Forest in America and Axel Petersen and Arnold Poulsen in Denmark, combining experiments with electricity and telecommunications. Competing inventions resulted in patent wars, culminating in global domination by American conglomerates Western Electric and the Radio Corporation of America (RCA). No women are mentioned in any of the histories documenting early film sound and acoustic technologies. Sound was considered a science that imposed itself on the art of film, which Dorothy Richardson famously named “The Film Gone Male” [sic]. Women had already made significant contributions to the development of early film criticism with Bryher, H. D. and Dorothy Richardson writing regularly for Close-Up, and C. A. Lejeune, Iris Barry, and Nerina Shute addressing an increasingly cine-literate female readership in the national press. To Richardson and other female writers, it seemed that sound cinema spoke to a masculine language group, becoming an instrument of "planful becoming" rather than the "purposeful being" of women (Richardson, 1932, p. 38), thus abandoning the feminine universalism of the silent film (Lant, 2006, p. 151).

Evidence suggests that the introduction of sound technology between 1929 and 1931 did few favors to women as producers, potential directors, writers, and musicians. Data gathered from British film production credits from the pre-sound 1920s shows that women constituted less than $1 \%$ of directors and designers, just over $1 \%$ of producers, and just over 13\% of writers. During the transition between 1929 and 1932 women accounted for just over $1 \%$ of directors, producers, and designers, just over $7 \%$ of writers, and around $2 \%$ of studio musicians and composers combined; but none worked in sound production (https://filmography.bfi.org.uk). These statistics are numerically so small that it is hard to draw meaningful conclusions. The upturn in women directors during the transition is a reflection of early sound films made by Elinor Glyn and Dinah Shurey, both of whom bankrupted themselves in the process. The downturn in women screenwriters to $6.6 \%$ out of 620 , represented a loss of around 48 women compared to the silent period.

Given the often bemoaned preponderance of "talk" in women's fiction and the skills of at least one successful 1920s woman scenarist-Lydia Hayward, noted for her clever dialogue titles-talking films might have been thought to be a gift to women scriptwriters and indeed, after a hiatus, Hayward did script a few remarkable films in the 1930s and 1940s (Gledhill, 2015). The downturn during the transition, then, may be a reflection of the early sound period's increase in talkie crime films adapted from popular male authors by all-male writing teams led by scriptwriters such as Edgar Wallace, Eliot 
Stannard, Charles Bennett, and Miles Malleson. Agatha Christie, whose The Passing of Mr. Quin was adapted to silent film in 1928 and Alibi to sound in 1931, was a notable exception as a female source.

The absence of women in sound production during the transition is borne out by the records of the Association of Cinematograph, Television and Allied Technicians (ACTT) formed in 1933. As Bell (2017) found, the 1936 record shows one unnamed woman sound cutter as the first and only woman in the entire decade to gain Union membership in sound. Unsurprisingly perhaps, given the BBC's emphasis on the science of sound and its marriage bar for women, it was an entirely male cohort of sound technicians, many BBC trained, who moved into newly equipped British sound studios such as Elstree, to develop cinema sound in what remains an overwhelmingly male-dominated sector to this day.

\section{Women Filmmakers in Late-Colonial India}

The social discrimination that women across the world faced as film professionals was inflected in the Indian subcontinent by the particularities of the social, religious, and political context. The following account, based on Debashree Mukherjee's research (2015, in press), focuses on Bombay cinema, but overlaps with conditions found in other Indian film production centers such as Lahore, Calcutta, Pune, and Madras.

In the early silent years, cinema was considered such a transgressive social force that few women were willing to associate themselves with the new medium. Gradually, women from professional performance backgrounds-dancers, singers, stage actresses, and courtesans-turned to cinema as a new and lucrative vocation. In early 20th-century India, the film actress quickly established herself as the main attraction of the movies; audiences were fascinated with images of "their" women available on screen in a society that still practiced purdah and gender segregation. By the mid-1920s, another class of women had found great success in the movies-Anglo-Indian women who were of mixed ethnicity and culturally less tethered to the social conservatism and gender rules of so-called "respectable" Hindu middle-class society. The "Anglo" tag was fluidly applied in late-colonial India and a whole range of minority female identities-mixed race, Jewish, Eastern European, Goan Christian-were subsumed under it, each at a different remove from the idea of "Indianness" that was being restructured as a nationalist response to colonialism.

Apart from acting, women worked as hairdressers, costume designers, film journalists, music composers, screenwriters, directors, and even producers. While the archive of Indian cinemas is fragmented and haunted by loss, one can find remarkable pioneers such as producer-directors Fatma Begum and Jaddanbai, music composer Saraswati Devi, director-actress Protima Dasgupta, actress-producers Devika Rani, Esther Abraham, and Begum Para, choreographer-dancer Azurie, screenwriter Snehprabha Pradhan, and film critics Clare Mendonca and Sushila Rani Patel. Alongside these high-profile practitioners labored scores of anonymous dancers, extras, seamstresses, and hairdressers, whose names we may never know. Together they constituted a vibrant class of cine-workers who defied hegemonies of class, caste, religion, and sexuality. Anglo-Indian actresses, Muslim courtesan-producers, Hindu 
queer directors, Christian journalists, and Parsi music composers routinely pushed the limits of progressive thought as visible, public, working women. It is important to emphasize the diversity of India's late-colonial female cine-workforce, not only to point to its radical, secular potential, but also to remember that pay scales, social prestige, and occupational precarities within the female workforce varied considerably. From sex workers to aristocrats, India's earliest female film professionals represented the full spectrum of existing social inequalities. For this same reason, India's film industries presented a vocational arena unlike any other. Urban workplaces offered women either blue-collar factory work or white-collar office work, women self-selecting on the basis of education, class, and community identity. Cinema, on the other hand, accommodated multiple genres of work and hence incorporated multiple types of women. The Bombay film industry in the 1920s and 1930s was a decentralized and unregulated space where finance flowed in through disparate channels and workers were not unionized. This created a remarkable space of opportunity as well as exploitation.

Female film practitioners were both a historical fact and a conspicuous social presence in late-colonial Bombay. However, even today there is little recognition of the role of women in the consolidation of South Asia's film industries. This is partly due to the fact that most of these women were rare exceptions in a male-dominated field, but mainly because of our historiographic-ideological blinkers as we assume women's absence rather than actively look for their presence. Given archival absences, it becomes incumbent on us not to replicate their silences in our own scholarly choices. Historiographic methods such as archival ethnography, reading against the grain, and speculative history offer powerful tools to push back against absence and mine parallel archives. A feminist film researcher who is alert to slim clues and traces will soon find that the "archive" is resonant with voices of women and their work. Alternate archival sites such as memoirs, autobiographies, interviews, and fiction often yield important historical information. At the same time, for those lower down in the industrial hierarchy even these tenuous clues are absent. In such cases Debashree Mukherjee found only an archive of exception-police files, newspaper reportage, court cases-where young women film workers are tried for theft, accuse employers of sexual assault, or are embroiled in domestic abuse cases. Additionally, South Asian film historiography is yet to study visual sites of documentation like production stills, publicity photographs, and family albums. It is at the site of visual memory that we might find both blurry and sharp traces of women's film work and professional lives.

\section{Women's Film Work "Below-the-Line" in the United States and Britain, 1930-1970}

While in the 1920s the accelerating professionalization of Hollywood noted earlier eased women out of the creative roles of director and producer, this did not stop women working in Hollywood. The business of large-scale filmmaking demanded an extensive workforce and thousands of women earned their living in the industry, often in assistant positions or service roles known in the business as "below-the-line." Dozens of deft-fingered girls worked in laboratories cutting negatives and splicing film, hundreds 
hand-embroidered garments for the studios' costume departments, while as the backbone of the animation industry scores of women inked, traced, and hand-painted animation cells. So numerous was the female workforce at Disney's Buena Vista studio that it was nicknamed "the nunnery." Similarly, women worked as clerical workers, secretaries, editors, wardrobe assistants, and studio researchers. They cut film, booked stars, sourced obscure props, painted sets, styled hair, designed, made and washed costumes, massaged egos, ran the rushes, and chauffeured directors. In sum, they were central to Hollywood's film production workforce after the transition to sound, the majority employed in the type of below-the-line roles that supported the work of producers.

Until relatively recently their labor was invisible in standard film histories of mainstream, sound cinema, for film historiography has privileged senior creative roles (directors, producers, studio heads), invariably writing a history of men. Attempts to recover women's below-the-line labor have been hampered by a lack of readily available documentation, compounded by assumptions that their work was of little value. In her study of women in the British film industry, Sue Harper (2000, p. 4) found that despite secretaries being "the grease which oiled the studio machine," there was "little surviving evidence about their labour and its complexities ... [as] few people thought to document them." Contemporaneous trade journals contain only male-authored, pejorative accounts of women's work in negative cutting, dismissing it as "routine stuff, done more often than not by girls with no pride or interest in their jobs" (Sainsbury, 1940, p. 95). The association between women's labor, its low status, and its place in the historical record has been a recurring theme in feminist film historiography, which repeatedly foregrounds the issue of archival absence and has developed innovative strategies to work with gaps and silences, fragments and unorthodox sources of documentation.

Recent revisionist research opens up new avenues for investigating such below-the-line roles. Taking the British film industry as example, by the 1930s its well-established infrastructure of studios, production companies, laboratories, distributors, and cinema chains employed several thousand specialist cine-workers. Melanie Williams (2013) has used nontraditional sources such as personal letters and memoirs to illustrate how women could exercise considerable agency through their role as continuity "girls," influencing the director's decisions and deputizing for him on the studio floor. Melanie Bell (in press) has used oral interviews to bring women's voices into film history, building a detailed picture of female-dominated occupations such as production secretary, and of women's high-level skills in logistics, problem-solving, and diplomacy. Researching such roles reveals both the processes through which women were excluded from top jobs-many still operative today-and the scale and quality of their collective achievements. Trade union records show how strongly, from 1930 onward, Britain's film workforce was unionized, setting rules of entry to the profession that privileged jobs and skills held by men, downgraded those possessed by women, and set in place occupational pathways and pay scales by gender. Jobs held by men-camera operator, draughtsman, first assistant director-were better paid than broadly equivalent jobs held by women such as wardrobe mistress and production secretary. And grades occupied by women had fewer occupational ladders than those held by men, leading to entrapment in what were recognized at the time as "blind-alley jobs" (Myers, 1947, p. 183). 
In the face of such prejudices and constraints, women in Britain's film studios poured their creative energies into the roles available to them, doing far in excess of their job descriptions; or they moved laterally into the documentary, shorts, or commercials sectors. Their reduced budgets, crews, and prestige, gave women more scope for career advancement. Sarah Erulkar built a long career as a director of factual shorts (between 1944 and 1983), marrying social comment with artistic inventiveness across a number of commissions on topics as diverse as helicopters, Indian dancing, and how to wash woollens. Her Picture to Post (1969) - commissioned by the General Post Office-won a BAFTA for best short film, while A World of Difference (1963) and Something Nice to Eat (1967) garnered lavish praise and widespread distribution on the nontheatrical circuit. Editors such as Monica Mead and Kitty Wood reported high degrees of professional autonomy in the nonfiction sector, characterizing freelance work for the National Coal Board as "marvellous" and "extraordinarily interesting" (cited in Bell, 2018, p. 48). And the art director Peggy Gick, who stepped back from feature films in the late 1940s when her children were born, found a new career in Britain's burgeoning commercials sector in the 1950s. Working on the Camay soap adverts-widely regarded in the industry as "the Ben-Hur of commercials"-gave Gick the opportunity to stretch herself creatively as they demanded glamorous sets, while, with a short production schedule of two to three days, she could fit work around childcare. These sectors afforded women like Gick, Erulkar, and many others professional opportunities that were less readily available in features.

Researching women's below-the-line work builds on the methodological protocols of film history, which adapt sociologically informed multimethod perspectives. These combine qualitative data (oral history, ethnographic methods), quantitative sources (labor records, census returns), and the materials of traditional film history (studio newsletters, production files, photographs) with an emphasis on ephemera including personal anecdotes, adverts, and "how-to" training manuals among others. Many women's voices lie buried in male-dominated collections, requiring some archival "heavy lifting" to bring them to light. Oral histories with women have been particularly illuminating, providing powerful accounts of everyday workplace processes and gendered practices that are frequently missing from more formal, written accounts. Feminist scholars have a long tradition of working with oral history to give unheard women a voice. By drawing across a wide range of materials/sources and adopting multimethod approaches, it is possible to bring women's below-the-line work into view. This enriches film scholarship and invites us to reflect on what counts as film history. Moreover, producing knowledge about the past empowers us to "disrupt the certainties of the present and ... imagin[e] a different future" (Scott, 2004, p. 24). At a time when women continue to face structural inequalities in the media workplace, better self-knowledge may have the power to effect change.

\section{Postwar Film Industries, the Women's Movement, and Feminist Filmmaking in Britain and America}

As in the 1930s, women struggled in the immediate postwar years to gain entry to the feature-film industry. In America, it took the collapse of the studio system following the 
antitrust Paramount decrees of 1948 and the consequent reemergence of independent companies to open opportunities for a few women to enter the industry as producers or directors-for example, Ida Lupino who made a number of women-inflected genre films. In wartime Britain, Ruby and Marion Grierson, and Jill Craigie worked in documentary-the latter making the postwar plea for equal pay, To Be A Woman (1951). But, as Harper (2000) suggests, the documentary movement's antipathy to fiction together with the masculinist attitudes of the film industry inhibited their crossing into fiction feature production. Craigie's only attempt, Blue Scar (1949), set against the nationalization of the coal industry, was initially refused exhibition.

Family connections enabled Betty Box, self-described as a "near-feminist" (Harper, 2000 , p. 155), to move from helping her producer brother Sydney on wartime propaganda shorts to head of production at Islington Studios. The only female major feature producer in 1950s Britain, she made gender- and class-conscious melodramas and comedies. Muriel Box moved from collaboration with her husband Sidney to become a successful director of films obliquely questioning gender and sexual identities. A similarly underlying edge is attributed to the films of Wendy Toye, who drew on her background in theatrical choreography and work with actors to combine fantasy with an emphasis on visual design.

The 1970s and 1980s constitute the era of feminist filmmaking. The women's movement, fueling second-wave feminism in America and Britain throughout the 1960s and 1970s, identified commercial film, magazine, and advertising cultures as sources of patriarchal misrepresentation and oppression. Critical debates on representation filled new magazines such as the American Women \& Film and British Spare Rib. New nonprofit film groups emerged in Britain, seeking alternative approaches for feminist and ethnic minority filmmaking, including the London Women's Film Group (1972-1977), Sheffield Film Cooperative (1973-1991), Leeds Animation Workshop (1978 to date), Black Audio Film Collective (1982-1998), and Sankofa (1983 to date). These initiatives emphasized collaboration, offered training, production facilities, and distribution, and different ways to engage audiences through discussion and debate. The influence of the London Women's Film Group, via the Independent Filmmakers' Association (1975-?), led to the ACTT, the industry trade union's 1982 Workshop Declaration, allowing grant-aided collectives to make films outside union restrictions. This enabled Sheffield Film Co-op to make their notable Women of Steel (1984) and Let Our Children Grow Tall (1986), and Sankofa's, Passion of Remembrance (1986). Crucially, new feminist distributors, Cinema of Women and Circles were founded to support circulation of women's films.

In America, Women Make Movies (1972 to date) grew from a filmmaking collective into a distribution company for women's films, with particular focus on films by women of color. In 1983, six women who were members of the Directors Guild Association brought a lawsuit against Hollywood studios, alleging discrimination against women directors; though they lost, the percentage of films and television directed by women in the following decade rose from 3\% to 9\%. In 1976 the Australian Film Commission's Women's Film Fund was established and produced several feminist films including For Love or Money: A History of Women and Work in Australia. Across North America and Europe, the rise of women's film festivals in the 1970s 
encouraged feminist filmmaking and the recognition of women's film history in their programming. Revivals of "forgotten" pioneers such as Alice Guy Blaché or of early experimental filmmakers such as American Maya Deren, were screened alongside classic Hollywood films and new women's movement documentaries such as Sue Crockford's A Woman's Place (1971) and Michelle Citron's Daughter Rite (1980), as well as avant-garde films such as Chantal Akerman's Jeanne Dielman ... (1975) and Yvonne Rainer's Film About A Woman Who ... (1974). These films in different ways challenged Hollywood representations of women and its linear narrative form, while the festivals made space to debate the role of women filmmakers in countering them.

Feminism's theoretical debates and the demand for alternative modes of filmmaking led women's filmmaking groups in different directions, oscillating between documentary as a means of capturing the conditions and experiences of "real" women's lives and an antirealist counter-cinema, influenced by arguments stressing the social construction of the real and psychoanalysis-influenced arguments against narrative forms, which, it was argued, positioned the spectator in a masculinized relation to woman as fetishized or voyeuristic object. In this context, counter-cinema flourished briefly. For example, Laura Mulvey and Peter Wollen's Penthesilea (1974) and Riddles of the Sphinx (1977) sought to deconstruct femininity, maternity, sexual difference, and identity, challenging the preeminence of narrative coherence and realism. Meanwhile in France, in the context of performance art, Greek theatrical and cinematic experimentalists Maria Klonaris and Katerina Thomodaki developed equally challenging filmmaking practices, focusing on the androgynous body and interchanging roles of cinematographer and subject in a cinéma corporal.

With a few exceptions, these feminist filmmaking collectives, distributors, and festivals, disappeared from the late 1980s onward, due to cuts and changes in funding both for and from arts organizations, broadcasters, and other public bodies enforced by the Thatcher and Reagan governments, and abetted by the backlash against feminism in the rising neoconservative culture of the 1980s, which resulted in the waning of women's consciousness-raising groups, university women's studies programs, and women's community centers, which had been key constituents of the feminist film movement.

\section{New German Cinema's Women Filmmakers}

In West Germany, the women's cinema movement (Frauenfilm) was part of the stateand television-subsidized but male-dominated New (West) German Cinema of the 1970s. Recognizing the need for an infrastructure to combat this gender inequality, Helke Sander organized with Claudia von Alemann in 1973 the first International Film Seminar and she founded in 1974 the feminist film journal Frauen und Film. For a few years, while under Sander's editorship, the journal became an important forum for discussing ideas and organizing practical issues, such as distribution, exhibition, film festivals, and the Association of Women Film Workers, founded in 1979.

Many women filmmakers had a political commitment to the left and were actively engaged in the women's movement, their prime concern being initially didactic socialism/feminism (i.e., "the personal as political"). In particular, television, such 
as the experimental drama department, Das kleine Fernsehspiel, offered first-time filmmakers, and therefore women, a chance. For many, authorship, or authorial control, came into play pragmatically in New German Cinema's more specific sense-namely involving the author/filmmaker across the range of filmmaking production stages. This artisanal mode of production was often determined by chronic underfunding rather than by aesthetic/ideological considerations. But it was thanks to this financial-pragmatic configuration that aspects of formal experimentation-often dismissed as amateurish-informed much of the work of New German Cinema in general, and specifically Frauenfilm. Exemplifying this early tendency are Sander's autobiographical Die allseitig reduzierte Persönlichkeit - Redupers, [All-round Reduced Personality] (1977), and Jutta Brückner's semi-autobiographical film Hungerjahre - in einem reichen Land [Hunger years] (1979). However, the mode of art cinema narration is the reference point for Helma Sanders-Brahms's better financed autobiographical film, Deutschland, bleiche Mutter [Germany, Pale Mother] (1980). This internationally acclaimed film was nationally controversial as it indicts patriarchy for the rise of fascism and the atrocities of war. Similarly, Margarethe von Trotta, who started her career as an actress, combines art cinema and melodrama for an engaged political cinema as exemplified by Die bleierne Zeit [The German Sisters] (1981).

However, the artistically trained Ulrike Ottinger, unlike many of her peers, rejected a realist treatment of women's issues, aiming for aural and visual pleasure-exaggeration, artifice, and parody. Her lesbian allegory Madame $X$ - eine absolute Herrscherin [Madame X - An Absolute Ruler] (1978) about a band of female pirates, provoked a mostly hostile response from feminists at the time. Yet, Ottinger's playful nondidactic approach, aimed at undermining male voyeurism, prefigured a more general 1980s tendency toward cine-feminism, which embraced formal play with audio visual elements as a means to express an embattled female subjectivity.

Alemann's Die Reise nach Lyon [Blind Spot] (1980) with its direct sound recording foregrounds the soundscape of the city rather than its images. Other new strategies that displace narrative derive from performance art, music, and spectacle, employed in filmmaking to explore female fantasy and psychic reality. Jutta Brückner's stylized theatricality and excessive artifice characterizes Ein Blick und die Liebe bricht aus [One Glance and Love Breaks Out] (1986). Similarly, Elfi Mikesch, also a much acclaimed cinematographer, foregrounds stylization in a film co-directed with Monika Treut, Verführung: die grausame Frau [Seduction: The Cruel Woman] (1985).

From the 1980s onward, West German state subsidies and, following the BaaderMeinhof attacks and subsequent emergency laws, ideological support for the New German Cinema, and thus the Frauenfilm, gave way to a more populist and genre-orientated cinema (e.g., the films of Doris Dörrie). Young women filmmakers, mostly film-school graduates, no longer explicitly identified as feminist filmmakers, perceiving this designation as undermining their apparent gender equality. Yet post-millennium, a new generation of remarkable female directors achieved both critical and commercial success-nationally and internationally. Foremost is Maren Ade, also a successful international producer, whose Toni Erdmann (2016) won a string of prestigious awards. Other internationally acclaimed women directors include Valeska Grisebach and Angela Schanelec. 
Among the original cine-feminists few remained active beyond 2000. While the majority of (West) German and international woman filmmakers have produced only intermittent, low-budget films and thus remained marginal, a long-distinguished career was granted to Von Trotta (last film 2017) and Sanders-Brahms (died 2014). Mikesch, too, is still working as a cinematographer. Significantly, though, the longevity of their careers was enabled by their status as acclaimed international auteurs rather than as part of women's cinema.

\section{Women Filmmakers from Pre- to Post-Independence Indian Cinemas}

The largely precarious and unorganized nature of the film industries in Bombay, Madras, Lahore, and Calcutta in the 1920s and 1930s, gradually led to the establishment of studios that functioned as close-knit units for film production as well as for training in all aspects of filmmaking. These studios offered greater stability to female workers, but also limited the flexibility that was characteristic of the earlier period. The imagination of the "family" as a blueprint for studio organization kept intact the structures of domination by male workers, in some instances, leading to public confrontations between male directors and producers and female actors seeking their dues.

To distinguish their identities, the studios developed individual aesthetic styles and work cultures, attracting particular kinds of actors, directors, editors, cinematographers, musicians. As M. Mukherjee (2009) notes, Calcutta's New Theatres produced quality cinema for the middle classes, an aspirational reference point, especially for the Bombay film industry. In Pune, the Prabhat Film Company sought educated and upper-caste women like Shanta Apte, Durga Khote, Shanta Hublikar, and others, thereby qualifying the film industry as a place where respectable women could work. In sharp contrast, was the Bombay-based Wadia Movietone, established by J. B. H. Wadia and Homi Wadia, producing stunt and action films, usually starring the Greek-Australian actress Mary Ann Evans, popularly known as "fearless Nadia," dressed in boots and trousers, and brandishing a whip.

While many of these studios survived until the late 1940s/1950s, after independence, the older concept of the studio as a closed family-style unit gave way to the less conservative values of a new set of production houses. In a newly independent federal, democratic republic, that had recently been partitioned and thus severed from large parts of its Muslim population, India faced the peculiar situation of having to quickly manufacture a national identity for a population whose language, food habits, cultural practices, and belief systems were dizzyingly varied, though only within a kilometer from each other. Not surprisingly, cinema led the march toward this national identity, and in recognition of its power over the people, the Film and Television Institute of India (FTII) was established in 1960 in Pune. For the first time, it became possible for women to seek professional training in filmmaking. Aruna Raje was the first woman to get a double diploma in direction and editing from FTII, and she subsequently worked in the Bombay film industry as a writer, director, and editor, making feminist films like Rihayee (1988). Nevertheless, the FTII operated a gender ratio that was hugely skewed, 
nurturing a doggedly patriarchal culture in both its policies and work practices. In its 50-year history, the institute has not appointed a single woman as director. Much of its misogynistic history, including cases of sexual harassment previously lodged by women but ignored, has become more clearly visible post the \#MeToo movement, leading in 2017 to the formation of the Indian Women in Cinema Collective in Kerala, in response to such cases exposed within the Malayalam film industry.

The establishment of state-funded production units such as the National Film Development Corporation (NFDC) in 1975 and the Public Service and Broadcasting Trust (PSBT) in 2000 supported films in regional languages. Like the FTII, these also presented challenges for women, but equally, they have been a source of funding and distribution. The combined effect of the FTII as training ground and the NFDC as funding source resulted in an increased number of women making films in the 1980s and after.

The feminist movement of the 1970s and 1980s, mobilized women to form collectives and work with communities, often using documentary film to draw attention to pressing issues. For example, the Yugantar Film Collective, formed by documentary filmmaker and activist Deepa Dhanraj and others, actively used collective/community-based filmmaking as a mode of activism as well as documentation. Their films are currently being restored in the Berlin film archive. From the 1980s onward, a small number of women's film festivals were organized, and popular press and media discussion drew attention to "women's films." Ironically, this discourse also had a negative impact, with some women filmmakers refusing gender labeling. Although women filmmakers gained some visibility through such festivals and wider public discussions, securing funds, distribution, and exhibition remained difficult.

In the 1980s, the national broadcaster Doordarshan commissioned telefilms, increasing opportunities for women to produce lower-budget films and also access a larger audience. Post-1990s, Indian media were opened to private investment, and new production houses were set up with relatively more experimental agendas. A significant number by women, including Red Chillies Entertainment co-founded by Gauri Khan, produced blockbuster films like Om Shanti Om (2007) and Chennai Express (2013), both starring her husband Shah Rukh Khan. Such husband-wife teams became a familiar production model in the Indian film industry. Other production houses include director-choreographer Farah Khan's unit, Three's Company (allegedly named after the birth of her triplets), Ekta Kapoor's Balaji Telefilms, which was a trendsetter in TV soap opera production, subsequently getting into film production, and Guneet Monga's Sikhya Films, supporting small-budget experimental films like Lunchbox (2013) and Shaitan (2011). The Malayalam and Tamil actor-director Revathy's production house, Telephoto Films, often works with an all-women or predominantly female production team and/or cast, for example, her directorial debut Mitr, My Friend (2002), which had a female director, cinematographer, scriptwriter, and editor.

Such examples show women contributing to Indian cinema in a wider range of capacities and deploying newer forms of collaboration and negotiation with the industry per se. This demands more in-depth enquiry into what it means to be a woman in the film industry today, taking into account large-scale technological changes, as well as the general climate of alertness mobilized by the \#MeToo phenomenon. 


\section{From the 1990s to \#MeToo}

Arguably, contemporary women's film history began around 1990. The early years of that decade mark the shift in anglophone countries from the second-wave feminism of the 1970s and the backlash of the 1980s to the postfeminism of the 1990s and early 2000s, a period in which feminist gains were partially normalized (access to education, work, and financial independence), and individual women's achievements were taken as evidence of feminism's simultaneous success and future irrelevance. For women's cinema, the popularity of Thelma \& Louise (1991) — directed by Ridley Scott but written by Callie Khouri, who won the Oscar for Best Original Screenplay with a script that rewrote a male genre and refused a happy ending-suggested a new era for women's films in Hollywood. Nevertheless, fictional film and TV representations of women fixated on the independent woman still seeking romance, marriage, and family (e.g., Sex and the City, 1998-2004). At the same time women made some gains within the industry. The 1993 Oscars were declared "The Year of the Woman" with 67 female winners in nonacting categories. The following year Jane Campion was the second woman ever to be nominated for the Best Director award for The Piano; she won the Oscar for Best Original Screenplay, and to this day remains the only woman to ever win the Palme d'Or at the Cannes Film Festival, for a film that foregrounded a woman's desires, arguably through a female gaze. Such awards matter because as exceptions they highlight the "complicated destiny of the female artist ... in a domain ... so frequently dominated by men" (Polan, 2001, p. 10).

Campion was the most high-profile woman among several veterans of the feminist filmmaking movement who during the 1990s crossed from small-scale experimental into more mainstream filmmaking. Their films were often financed by multiple international co-production and distribution deals with a range of independent companies, arts organizations, or state film-funding bodies. Several were adaptations of women's novels_-such as Sally Potter's Orlando (1991), Patricia Rozema's Mansfield Park (1999), and Marleen Gorris's Mrs. Dalloway (1997). These films, foregrounding a female perspective, arguably initiated an era of female auteurs making independent cinema. These include Sofia Coppola, Lynne Ramsay, Lisa Cholodenko, Debra Granik, Courtney Hunt, Gurinder Chadha, Julie Dash, and many more. Often their films center on women in traditionally masculine genres. These anglophone filmmakers are only one part of a wider global resurgence of women filmmakers making independent films that have achieved critical acclaim and success on a festival circuit that has boomed since the early 1990s: for example, Lucrecia Martel (Argentina), Deepa Mehta (India-Canada), Zero Chou (Taiwan), Claudia Llosa (Peru), and Claire Denis (France), not forgetting the influential French art cinema auteur, Agnès Varda, who continued working through feminist and postfeminist periods.

American women directors also moved from feminist independent filmmaking groups into mainstream genres for independent studios during the late 1980s and early 1990s. Lizzie Borden, known for the independently made feminist polemic, Born in Flames (1983), made Love Crimes about a female detective in 1992, and Martha Coolidge, who started out making feminist documentaries, directed the comedy Real Genius (1985). By the time Kathryn Bigelow made Point Break in 1991, she had 
established herself as an independent director of genre-bending films such as Near Dark (1987) and Blue Steel (1990) about a female cop. Bigelow was the first, and to date the only, woman to win the Best Director Oscar at the 82nd Academy Awards for her film The Hurt Locker (2009) about a bomb disposal expert in the Iraq War. She has become known for making films about men in male genres, defying the expectation that women filmmakers will make films about women. At the same time, some women were making female-oriented comedies for the big Hollywood studios. Penny Marshall, who was the first woman director to break the $\$ 100$ million box-office mark for Big (1988) also made A League of Their Own (1992) about an all-female baseball team during World War II. Other financially successful women in Hollywood include the romantic-comedy writer-directors Nora Ephron, famous for Sleepless in Seattle (1991) and Nancy Meyers, known for What Women Want (2000). Often derided by commentators and critics as lightweight, the films by these women have found new appraisal by feminist film scholars such as Deborah Jermyn (2017) for their negotiation of genre conventions and scripts about older women claiming their right to romance.

The second decade of the new millennium in Hollywood, known as "the franchise era," continues to make space for some exceptional women and has generated more firsts. Patty Jenkins whose blockbuster Wonder Woman (2017) and Anna Boden who co-directed, with Ryan Fleck, Captain Marvel (2019) are the first women to direct, respectively, a DC Comics and Marvel adaptation in this period of popular superhero films. Ava DuVernay was the first Black Woman to have a film budget of over US\$150 million for A Wrinkle in Time and her smaller-budget film Selma (2014) made her the first Black American woman to be nominated for Best Director at the Golden Globes and the first to have her film nominated for a Best Picture Oscar. These groundbreaking big studio hires and award nominations continue the postfeminist focus on individually successful women in the media, inviting claims for the industry's shift from gender discrimination. However, evidence shows that both Hollywood and the independent sector are riddled with gender inequality, and after initial success, a woman's second film becomes more difficult to finance. Data from the Center for the Study of Women in Television \& Film at San Diego State University shows that women made up $29 \%$ of all directors of independent films screened at American film festivals in 2018, well below gender parity, albeit an increase on the earliest data from 2008 of $22 \%$ films directed by women. And of the top 250 grossing films of 2018 , only $8 \%$ were directed by women, a decrease from the $9 \%$ recorded in 1998.

Entrenched inequality provides the wider context for the exceptional women noted earlier, who are currently recognized as memorable. But their exceptionalism has also been used to deflect the general rule of inequality, implying that those who do not succeed simply lack talent or drive. If in the 2010s, increased media attention is paid to women's filmmaking and the problem of inequality, this can partly be attributed to the rise of the internet: the educational and agitational website "Women and Hollywood" has been amplifying these issues since 2007. Social media, which has facilitated what some are calling the fourth digital wave of feminism, provided the means for the \#MeToo movement to spread quickly after Harvey Weinstein, the former head of Miramax (which produced a number of films by the women listed 
earlier), was exposed as a sexual predator. Now \#Time'sUp and its legal defense fund help women who have been harassed on the job to hire lawyers (not just in the film industry). These movements and campaigns can be linked to the consciousness-raising and collective action of the feminist film era. But even as they try to recognize women who had already worked against harassment and inequality-like Tarana Burke and Anita Hill-such movements remain largely top-down, run by wealthy stars and studio heads. And inequality for women filmmakers continues. The current popular feminist focus on gender inequality in the system is, arguably, not as much of a break from postfeminist claims that feminism is over as it might seem when cultures of sexism remain and successes at the individual level are held as the answer. However, these collective campaigns and the high profile of the woman filmmaker are recent developments and it remains to be seen if a radical change in women's film history is forthcoming. In recognizing the contemporary as part of women's film history, the excavating, archiving, and memory work of women film historians reveal how women's past endeavors anticipate the issues of our present, pointing, through us, to possible futures.

SEE ALSO: Archives of Women's Media; British Women's Amateur Film Production; Gendered Representation in Postcolonial India; Leeds Animation Workshop; Researching Women's Television History; Women and Cinematography

\section{References}

Allen, J. (2017). Asta Nielsen. Retrieved from https://wfpp.cdrs.columbia.edu/pioneer/astanielsen-2

Bell, M. (2017). Learning to listen: Histories of women's sound work in the British film industry. Screen, 88(4), 437-457.

Bell, M. (2018). Rebuilding Britain: Women, work and non-fiction film 1945-1970. Feminist Media Histories, 4(4), 33-56.

Bell, M. (in press). Women at work in the British film industry: A feminist history, 1933-1989 (working title). Urbana: University of Illinois Press.

Cooper, M. (2013). Universal women. Urbana: University of Illinois Press.

Dall'Asta, M., \& Gaines, J. M. (2015). Prologue: Constellations: Past meets present in feminist film history. In C. Gledhill \& J. Knight (Eds.), Doing women's film history: Reframing cinemas, past and future (pp. 13-25). Urbana: University of Illinois Press.

Davy, C. (1926, November 29). Yorkshire Post. Archive: The Sidney Carroll Scrapbook, British Film Institute Special Collections.

Dixon, A. A. (2016). Early African-American female filmmakers. In M. Bridges \& C. Robson (Eds.), Silent women: Pioneers of cinema (pp. 35-68). Twickenham, UK: Supernova.

Gaines, J. M. (2018). Pink slipped: What happened to women in silent film industries? Urbana: University of Illinois Press.

Gledhill, C. (2015). Lydia Elizabeth Hayward (1879-1945). In J. Nelmes \& J. Selbo (Eds.), Women screen writers: An international guide (pp. 610-619). Basingstoke, UK: Palgrave Macmillan.

Harper, S. (2000). Women in British cinema: Mad, bad and dangerous to know. London, UK: Continuum.

Hayward, L. (1927, June 18). Concerning scenarios. The Bioscope, 155. 
Hershfield, J., \& Torres San Martín, P. (2013). Writing the history of Latin American women working in the silent film industry. Retrieved from https://wfpp.cdrs.columbia.edu/essay/ writing-the-history-of-latin-american-women-working-in-the-silent-film-industry

Jermyn, D. (2017). Nancy Meyers. London, UK: Bloomsbury Academic.

Lant, A. (2006). Red velvet seat: Women's writing on the first fifty years of cinema. London, UK: Verso.

Mahar, K. W. (2006). Women filmmakers in early Hollywood. Baltimore, MD: John Hopkins University Press.

Martin, A. (1998). “Gilda didn't do any of those things you've been losing sleep over!": The central women of 40s film noir. In E. A. Kaplan (Ed.), Women in film noir (pp. 200-228). London, UK: BFI.

McKernan, L. (2015). Searching for Mary Murillo. In C. Gledhill \& J. Knight (Eds.), Doing women's film history: Reframing cinemas past and future (pp. 78-92). Urbana: University of Illinois Press.

Mukherjee, D. (2015). Bombay modern: A history of film production in late colonial India (Unpublished doctoral thesis). New York University, New York.

Mukherjee, D. (in press). Bombay hustle: Making movies in a colonial city. New York, NY: Columbia University Press.

Mukherjee, M. (2009). New Theatres Ltd: The emblem of art, the picture of success. Pune: National Film Archive of India.

Muscio, G. (2015). American women screenwriters in the 1920s. In C. Gledhill \& J. Knight (Eds.), Doing women's film history: Reframing cinemas, past and future (pp. 193-205). Urbana: University of Illinois Press.

Myers, J. B. (1947). Film publicist. In O. Blakeston (Ed.), Working for the films (pp. 178-183). London, UK: Focal Press.

Polan, D. (2001). Jane Campion. London, UK: BFI.

Richardson, D. (1932). Continuous performance: THE FILM GONE MALE. Close Up, 9(1), 36-38.

Sainsbury, F. (1940). Close-Ups, No. 8: The Johnstone Sisters. Cine-Technician, Oct.-Dec., pp. 94-95.

Scott, J. W. (2004). Feminism's history. Journal of Women's History, 16(2), 10-29.

Tomadjoglou, K. (2015). Alice's great cinematic adventure. In C. Gledhill \& J. Knight (Eds.), Doing women's film history: Reframing cinemas, past and future (pp. 95-109). Urbana: University of Illinois Press.

Wei, S. L. (2017). Helen Wang. Retrieved from https://wfpp.cdrs.columbia.edu/pioneer/helenwang

Wei, S. L. (2018). Yang Naimei. Retrieved from https://wfpp.columbia.edu/pioneer/yangnaimei

Williams, M. (2013). The continuity girl: Ice in the middle of fire. Journal of British Cinema and Television, 10(3), 603-617.

Yang, P. (2017). Fan Xuepeng. Retrieved from https://wfpp.columbia.edu/pioneer/fan-xuepeng

\section{Further Reading}

Chich, C. (2015). A major contribution to feminist film history: Maria Klonaris and Katerina Thomadaki's cinéma corporel (cinema of the body). In C. Gledhill \& J. Knight (Eds.), Doing women's film history: Reframing cinemas, past and future (pp. 110-126). Urbana: University of Illinois Press.

Cobb, S., \& Horeck, T. (2018). Post Weinstein: Gendered power and harassment in the media industries. Feminist Media Studies, 18(3), 489-491. 
Davy, C. (1938). Footnotes to the film. London, UK: Lovat Dickson.

Gaines, J., Vatsal, R., \& Dall'Asta, M. (2013). Women film pioneers project. Center for Digital Research and Scholarship. New York, NY: Columbia University Libraries.

Majumdar, N. (2009). Wanted cultured ladies only: Female stardom and cinema in India, 1930s-1950s. Urbana: University of Illinois Press.

Sawhney, R. (2007). Apotheosis or Apparition? Bombay and the village in 1990s women's cinema. Film Studies, 11, 1-13. (Special issue on "Visualising the city").

Sawhney, R. (2015). Revising the colonial past, undoing national histories: Women filmmakers in Kannada, Marathi and Bengali cinemas. In C. Gledhill \& J. Knight (Eds.), Doing women's film history: Reframing cinemas, past and future (pp. 151-165). Urbana: University of Illinois Press.

Thomas, R. (2005). Not quite (pearl) white: Fearless Nadia, queen of the stunts. In R. Kaur \& A. J. Sinha (Eds.), Bollyworld: Popular Indian cinema through a transnational lens (pp. 35-69). New Delhi, India: Sage.

Women's Film \& Television History Network-UK/Ireland. Retrieved from http://womensfilmandtelevisionhistory.wordpress.com/

Women Film Pioneers Project. Retrieved from https://wfpp.cdrs.columbia.edu/

Melanie Bell is associate professor in film and media studies at the School of Media and Communication, University of Leeds, UK. She has published widely on gender and film including Femininity in the Frame: Women and 1950s British Popular Cinema (2010), British Women's Cinema (2010), and Julie Christie (2016). Her monograph, Women at Work in the British Film Industry: A Feminist History, 1933-1989 (working title) will be published by the University of Illinois Press in 2020.

Shelley Cobb is associate professor of film in the Faculty of Arts and Humanities, University of Southampton, UK. She is the author of Adaptation, Authorship and Contemporary Women Filmmakers (Palgrave, 2015) and the principal investigator on the AHRC-funded research project "Calling the Shots: Women and Contemporary Film Culture in the UK, 2000-2015.”

Christine Gledhill is visiting professor in cinema studies at the University of Leeds and co-founder of the Women's Film \& Television History Network-UK/Ireland. She has published widely on feminist film criticism, film genre, melodrama, British cinema, stardom and the actress, including her edited anthology, Home is Where the Heart Is: Studies in Melodrama and the Woman's Film (1997), and her monograph Reframing British Cinema, 1918-1928: Between Restraint and Passion (2003). She has recently coedited with Julia Knight, Doing Women's Film History: Reframing Cinemas, Past and Future (2015), and with Linda Williams, Melodrama Unbound (2018).

Debashree Mukherjee is assistant professor of film and media in the Department of Middle Eastern, South Asian, and African Studies at Columbia University in New York. Her forthcoming book Bombay Hustle: Making Movies in a Colonial City (Columbia University Press) presents a practitioner's eye view of the emergence of the Bombay film industry, drawing inspiration from her own experience of working in Mumbai's film and television industries. She edits the peer-reviewed journal BioScope: South Asian 
Screen Studies, and her research interests include media technology studies, feminist historiography, industry studies, environmental humanities, and histories of labor.

Laraine Porter is reader in cinema history at the Institute of Cinema and TV History at De Montfort University, Leicester. She was the principle investigator on a recent Arts and Humanities Research Council project, "British Silent Cinema and the Transition to Sound 1927-1933." She has published journal articles and book chapters on British silent and early sound cinema including women cinema musicians and the women's voice in cinema. Her current research is on women working across the transition to sound and the reception of the talkies in Britain. She is the co-director of the British Silent Film Festival, which has been running since 1998.

Rashmi Sawhney is associate professor of cinema and cultural studies at Christ University, Bangalore. She writes on cinema and visual culture with a focus on India, and curated Video Vortex XI (an international exhibition of video installations) as a collateral of the Kochi-Muziris Biennale in 2017. Her most recent publications include a special issue of MIRAJ on South Asian Artists' Film and Video (2018) and a chapter in Gledhill and Knight (Eds.), Doing Women's Film History (2015). She is currently working on a book manuscript on women filmmakers in India, and an edited anthology on film and television in post-1990s India.

Ulrike Sieglohr is an honorary research associate in film, television, and radio studies at Staffordshire University, UK. Her research interests include New German Cinema, German cinema, opera and cinema, independent women filmmakers and sound, on which she has published numerous articles, including her edited collection Heroines Without Heroes: Reconstructing Female and National Identities in European Cinema, 1945-51 (2000), and a monograph, Hanna Schygulla (2014). 